\title{
Extreme cultural persistence in eastern-central Brazil: the case of Lagoa Santa Paleaeoindians
}

\author{
ASTOLFO G.M. ARAUJO ${ }^{1}$, FRANCISCO A. PUGLIESE JR. ${ }^{2}$, RAFAEL \\ O. DOS SANTOS ${ }^{3}$ AND MERCEDES OKUMURA ${ }^{4}$ \\ ${ }^{1}$ Institute of Advanced Studies and Museum of Archaeology and Ethnology, University of São \\ Paulo, Av. Prof. Almeida Prado, 1466, Butantã, 05508-070 São Paulo, SP, Brazil \\ ${ }^{2}$ Museum of Archaeology and Ethnology, University of São Paulo, Av. Prof. \\ Almeida Prado, 1466, Butantã, 05508-070 São Paulo, SP, Brazil \\ ${ }^{3}$ National Indian Foundation (FUNAI), Coordenação Regional Xavante, Rua Amaro \\ Leite, 467, Centro, 78600-000 Barra do Garças, MT, Brazil \\ ${ }^{4}$ PPGArq, Dept. of Anthropology, National Museum, Federal University of Rio de Janeiro, \\ Quinta da Boa Vista, São Cristóvão, 20940-040 Rio de Janeiro, RJ, Brazil \\ Manuscript received on February 13, 2017; accepted for publication on April 13, 2017
}

\begin{abstract}
Lapa do Santo rockshelter, a Paleoindian site located in Eastern-Central Brazil, presented two main occupations; one during Early Holocene (12,460 to 8700 cal BP), and a latter in Middle Holocene (5100 to $4200 \mathrm{cal} \mathrm{BP}$ ). In spite of this 3600 year gap, the stratigraphy and general characteristics of the material culture did not indicate any visible discontinuity. This led us to hypothesise a reoccupation of the rockshelter by the same cultural group, tested by means of statistical analyses comparing lithics, bone artifacts, and faunal remains from early and middle Holocene layers. No significant differences were found, and our results indicate the presence of a cultural tradition that persisted for 8240 years, or roughly 412 generations.
\end{abstract}

Key words: cultural persistence, cultural transmission, lithic technology, zooarchaeology, Paleoindian, South America.

\section{INTRODUCTION}

Paleoindian sites in the Lagoa Santa area, EasternCentral Brazil (Figure 1), are well known and widely published (Araujo et al. 2008, Araujo and Neves 2010, Araujo et al. 2012, Laming-Emperaire et al. 1975, Neves et al. 2004, Neves et al. 2013, Neves and Hubbe 2005, Strauss et al. 2015). The Paleoindian occupation of this area is considered

Correspondence to: Astolfo Gomes de Mello Araujo

E-mail: astwolfo@usp.br

* Contribution to the centenary of the Brazilian Academy of Sciences. to span an interval between ca. 12,600 to 8500 cal $\mathrm{BP}^{1}$ (Araujo et al. 2012), and most sites are inside rockshelters. The occurrence of gaps in the human occupation of Lagoa Santa during the middle Holocene was acknowledged a decade ago (Araujo et al. 2005, Araujo et al. 2006), and the end of the Paleoindian occupation in the region was considered to be marked by the general abandonment of the rockshelters at 8500 cal BP.

${ }^{1}$ All radiocarbon dates calibrated using CalPal 2007 (Weninger et al. 2012). 


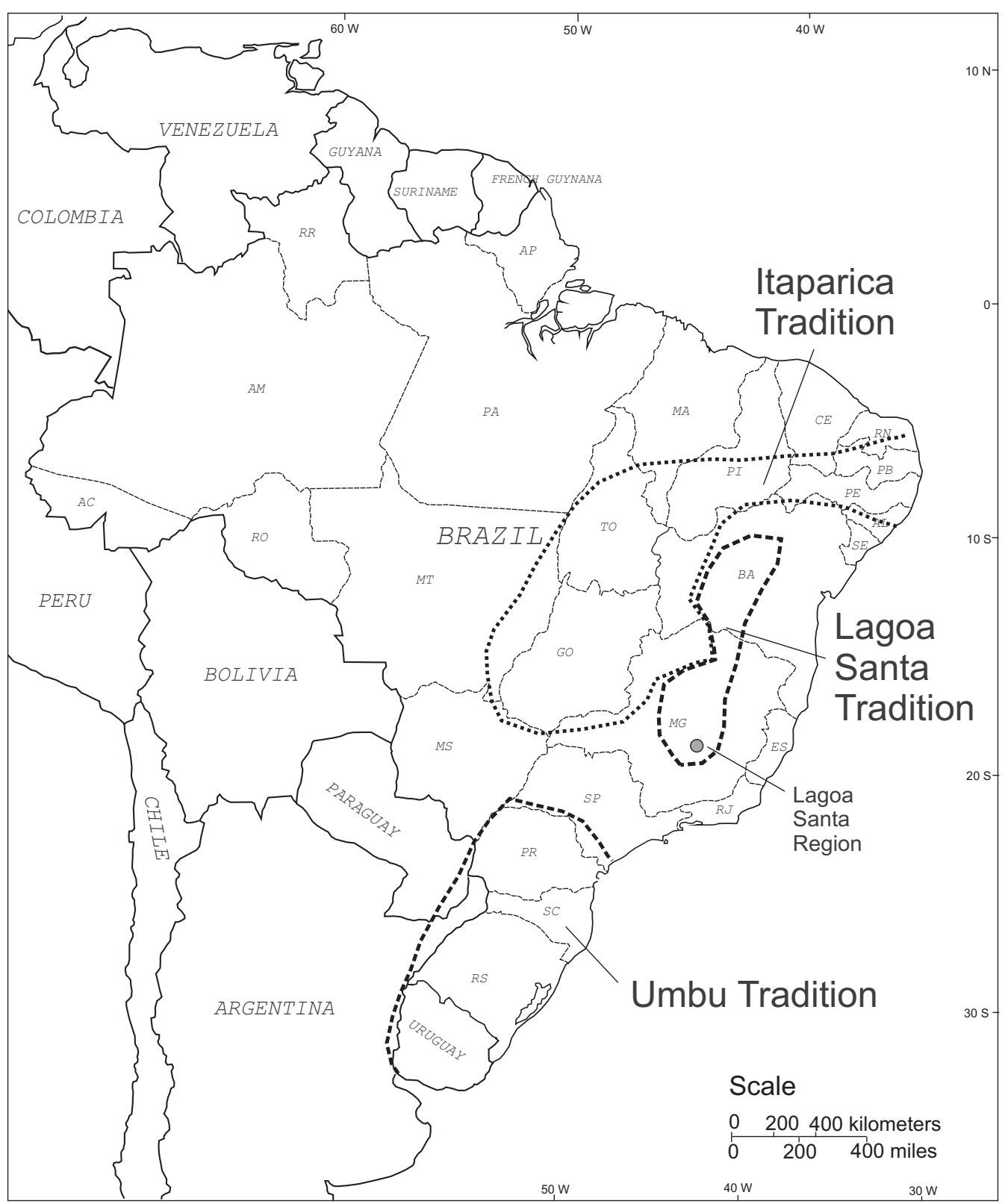

Figure 1 - Eastern South America and approximate areas of occurrence of Umbu, Lagoa Santa and Itaparica traditions.

The infilling sediments at these rockshelters are predominantly anthropogenic, in the form of wood ash (Araujo 2008, Araujo et al. 2008, 2012). This means that periods of site abandonment tend to halt the accumulation of sediment, and large gaps in chronology can go unnoticed during excavation. More recently, with the increase of the radiocarbon database for the Paleoindian occupations, it was possible to recognize a short interval of time when the largest rockshelter of the region, Lapa do Santo (Araujo et al. 2012, Neves et al. 2012), was reoccupied. As a consequence, human activities inside the rockshelter resulted in the massive accumulation of wood ash in the same manner as before. After this reoccupation, the rockshelter was abandoned again, not to be occupied intensively 
anymore. What really surprised us were the ages obtained: the reoccupation took place between 5100 and 4200 cal BP and, therefore, well out of the range of what we consider as the Paleoindian Period. This short reoccupation event gave us a clue about the possibility that the Lagoa Santa Paleoindians, in spite of moving away from the core area, maintained their culture during a time span that was much longer than previously acknowledged. In order to test this assumption, we compared the early and middle Holocene archaeological layers, both from the technological (stone and bone artifacts) and subsistence (faunal remains) points of view. Data from other Paleoindian sites from the same region (Lapa das Boleiras and Lapa de Taquaraçu, Figure 2) were also explored.

\section{LAPA DO SANTO ROCKSHELTER}

Lapa do Santo is the largest known rockshelter with archaeological remains in the Lagoa Santa region, comprising the sheltered entrance of a cave, $70 \mathrm{~m}$ long and $20 \mathrm{~m}$ wide, with an area of 1,300 $\mathrm{m}^{2}$, opening towards the west (Figure 3). Between 2001 and 2009 a team led by Walter Neves and Renato Kipnis, from the University of São Paulo, excavated an area of $44 \mathrm{~m}^{2}$, uncovering a very deep stratigraphy that reached more than $4 \mathrm{~m}$ in some parts (Araujo 2008, Neves et al. 2012).

When one approaches the rockshelter today, it is possible to note an inclination of the floor towards the north, whose bottom reaches a sinkhole. The southern portion of the shelter is much higher, and it is necessary to climb up a small hill in order to reach the south wall. If one proceeds eastwards, in the direction of the back wall, the topography will go down again. After several years of excavation it was possible to acknowledge that this "hill" was not natural, but the result of the accumulation of cultural materials in the form of ash, burned earth, bones, stone tools, plant remains, limestone pebbles and human burials. This fact became clear when we reached the original floor of the rockshelter inside a $4 \mathrm{~m}^{2}$ excavation (units F12, F13, G12, and G13, Figure 3a) and found that the bottom of the archaeological sequence was topographically in the same level of the natural cave floor. Moreover, we were able to discover rock art (petroglyphs) in the large blocks that were part of the original floor, with a minimum age of 10,000 calBP (Neves et al. 2012). In the northeastern portion of the site there is a rich rock art panel, with anthropomorphic and zoomorphic figures pecked over the limestone floor and showing the same aspect of the ones found in the excavation.

The site seems to be a central place in terms of the ancient Paleoindian settlement system, the only rockshelter in the region that showed such an accumulation of cultural materials, rock art, and human burials (26 human burials that were recovered in a $15 \mathrm{~m}^{2}$ excavation area - Strauss 2010). We have good reason to believe that the original sediment thickness surpassed the extant numbers considerably, since the top of the archaeological sequence was partially removed by gravity (soil creep) from its original position in the upper parts of the hill, and re-deposited in the lower parts. The dating results from the top layers of the site often provided ages ranging between 8500 to 9000 calBP. The only exception was found in the excavation units that were placed on the highest part of the hill, the "M units".

\section{The M Units}

We will focus our analyses on the five units that were excavated together (units M3, M4, M5, M6, and M7), forming a trench $5 \mathrm{~m}$ long and $1 \mathrm{~m}$ wide (see Figure 3a). The flat surface of the floor, allied to the presence of a large limestone block and ultimately to the fall of a large stalactite that served as a wall, precluded the erosion of the sediment in this portion of the site. All excavation areas inside the site were subject to dating (see complete list 


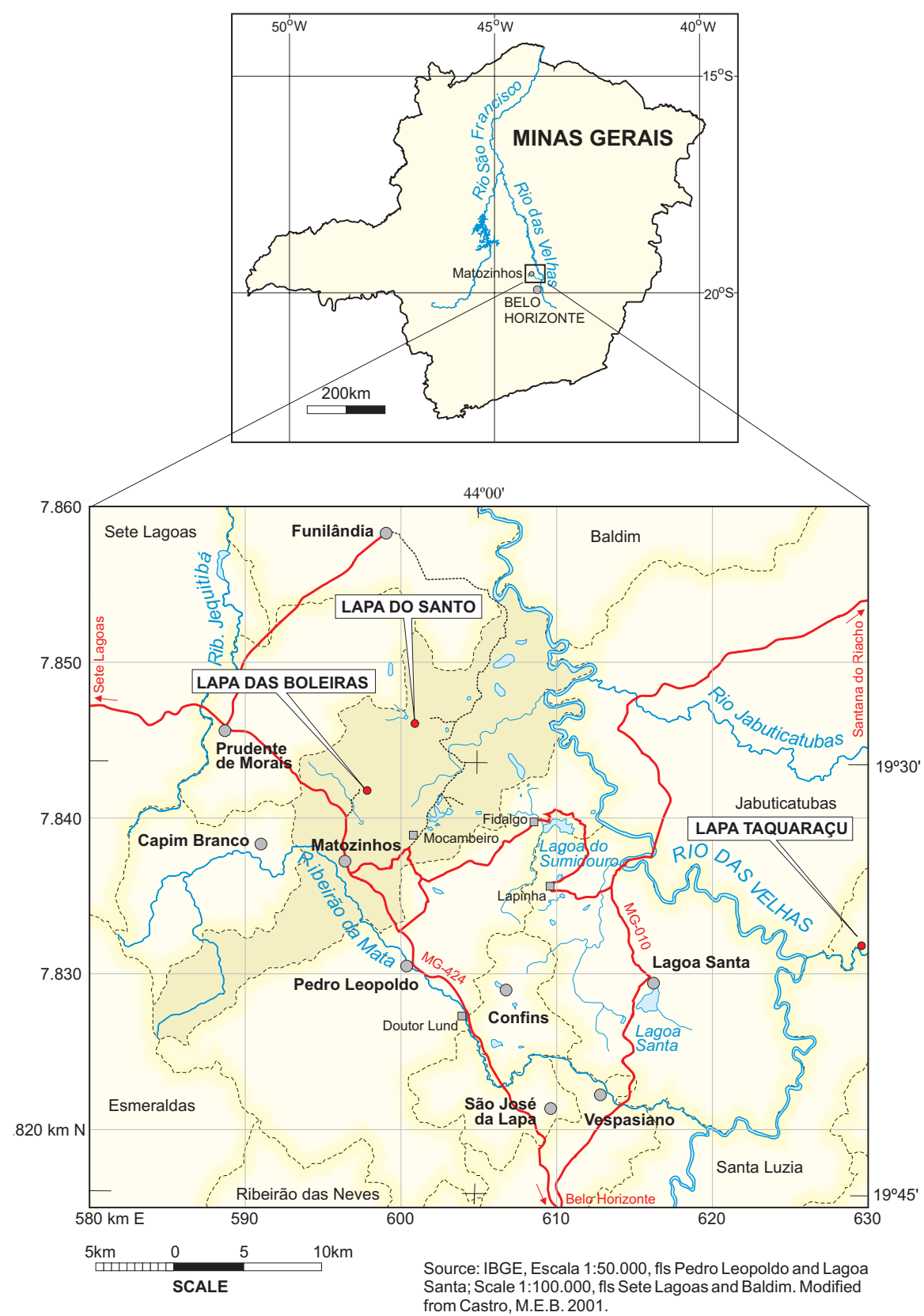

Figure 2 - Location of Lagoa Santa region and sites mentioned in the text.

of obtained ages in Araujo et al. 2012), and the only instance of mid-Holocene ages in undisturbed stratigraphy was found at the M units. This means that the $\mathrm{M}$ units are located at the only portion of the site that contains a complete cultural sequence for Lapa do Santo Paleoindian occupation.

The excavation was carried out according to a mixed strategy of decapage following natural layers and, at the same time, the recording of the excavation at least every $10 \mathrm{~cm}$ (photographs and drawings of each unit). The recognition of different archaeological facies (sensu Stein et al. 1992, Araujo et al. 2010) during the excavation involved the separate sieving and collection of sediment samples for each one of them, and also the designation of individual archaeological pieces 
LAPA DO SANTO ROCKSHELTER
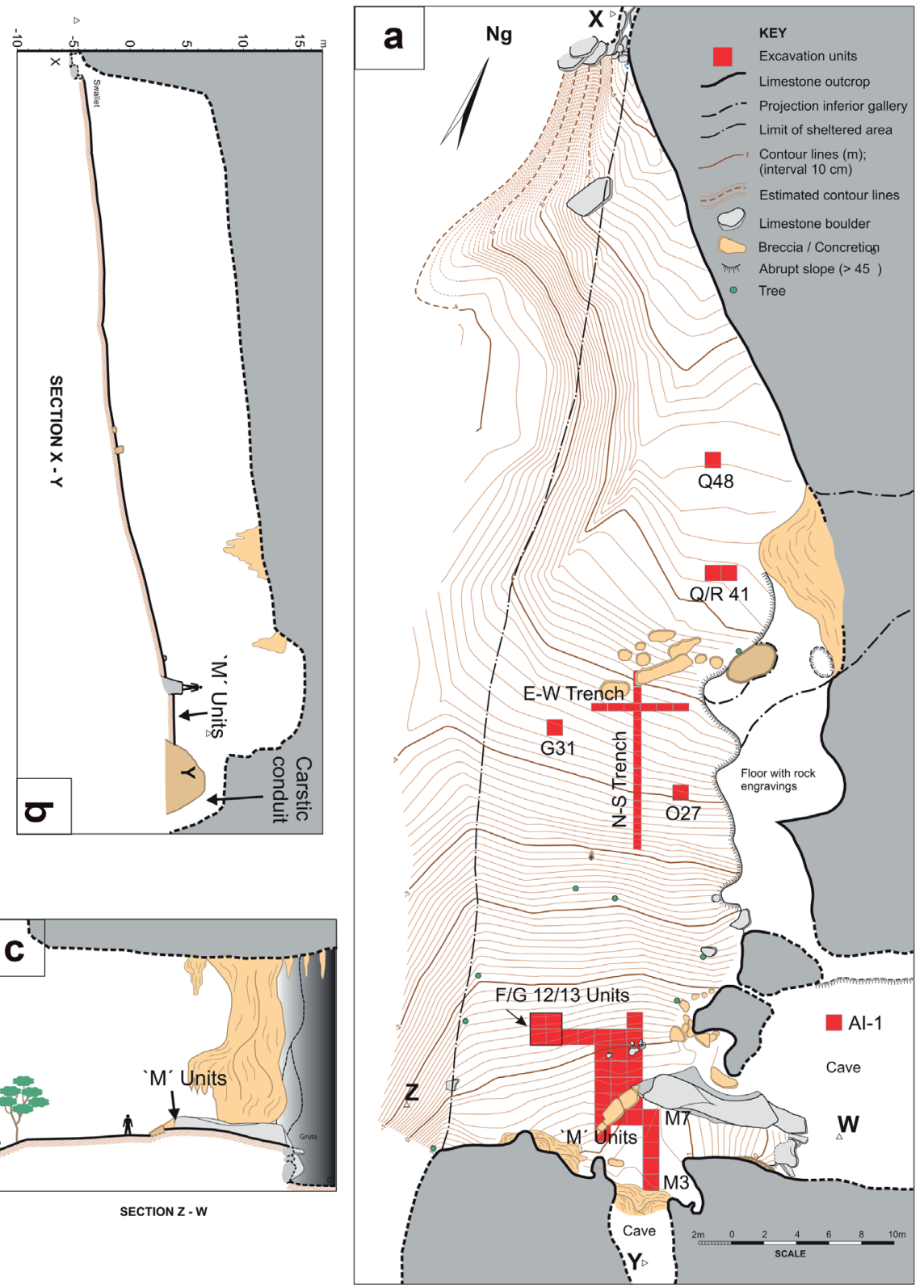

Figure 3 - Map of Lapa do Santo rockshelter, showing the excavation areas and topographic sections.

to particular facies. Archaeological materials larger than $2 \mathrm{~cm}$ had their coordinates recorded individually by means of a total station.

Several features comprising discreet charcoal accumulations and animal bones were observed during the excavation, and were interpreted as hearths. No human remains were found in this portion of the site. The stratigraphy of the $\mathrm{M}$ units showed well preserved layers of ash, following a dip from north to south in the lower layers and a more horizontal aspect in the upper layers. In contrast to the lower layers, the upper layers were somewhat disturbed, showing the presence of pits. It is possible to observe a subtle difference in the 
general color of the sediments between the turbated layers in the top and the flat layers in the middle of the stratigraphic sequence (Figure 4).

\section{SITE FORMATION PROCESSES AND CHRONOLOGY}

The obtained chronology for the M units (Table I; Figure 4) shows a marked hiatus in the stratigraphy. The bottom of the excavation at the $M$ units produced an age of 10,060 \pm 100 calBP $(8930 \pm 40$ $\left.{ }^{14} \mathrm{C} \mathrm{BP}\right)$. With time, there was an upbuilding of ash and other anthropogenic materials that resulted in a $1 \mathrm{~m}$ thick sediment column, up to $9140 \pm 90$ calBP $\left(8170 \pm 50{ }^{14} \mathrm{C} \mathrm{BP}\right)$. Then, suddenly, the chronology jumps to $4860 \pm 150$ calBP $\left(4290 \pm 90{ }^{14} \mathrm{C} \mathrm{BP}\right)$, without any significant change in color or other macroscopic characteristics of the sediment. This indicates a hiatus of 4280 years in the stratigraphy at this specific portion of the site. Overall, taking into account the whole suite of radiocarbon ages, the hiatus in the occupation of the site spans 3600 years. On the top of the sequence, a thin layer of recent (ca. $900{ }^{14} \mathrm{C} \mathrm{BP}$ ) sediments is also present. This means that there are two markedly different occupations, one dating from the early Holocene, and the other from the middle Holocene. The difference in sediment color mentioned above is found within the middle Holocene layers. This hiatus in sedimentation, without any evidence of erosion (truncation) or deposition of a sterile layer, is the strongest indicator of the anthropogenic nature of the sediments at Lapa do Santo. The absence of sedimentation is linked to the absence of human activity. Specifically at the M units, there is no possibility of any geogenic sediments entering the sheltered area, either by cracks on the ceiling or by karstic conduits bringing soil from the upper parts of the massif. The only karstic conduit close to the $\mathrm{M}$ units goes down, and therefore cannot act as a sediment source (Figure 3b). The same phenomenon was observed in another rockshelter,

TABLE I

Radiocarbon ages for the M Units, Lapa do Santo. Calibrated ages obtained using CalPal 2007 (Weninger et al. 2012 ).

\begin{tabular}{|c|c|c|c|c|c|c|c|c|c|c|c|}
\hline Sample & $\begin{array}{l}\text { Lab \# } \\
\text { (Beta) }\end{array}$ & Material & Unit & Level & Facies & $\mathbf{X}$ & $\mathbf{Y}$ & $\mathbf{Z}$ & $\begin{array}{l}\text { Conventional } \\
\text { 14C Age BP }\end{array}$ & $\begin{array}{c}13 \mathrm{C} / 12 \mathrm{C} \\
(\mathrm{o} / \mathrm{oo})\end{array}$ & Cal Age BP \\
\hline 45 & 202764 & Wood charcoal & M05 & 2 & 2 & 12.630 & 4.860 & 1.097 & $910 \pm 50$ & -25.6 & $840 \pm 60$ \\
\hline 47 & 183572 & Wood charcoal & M05 & 3 & 2 & 12.582 & 4.807 & 0.994 & $960 \pm 70$ & -25.0 & $880 \pm 70$ \\
\hline 59 & 202766 & Wood charcoal & M05 & 8 & 9 & 12.459 & 4.561 & 0.431 & $3810 \pm 50$ & -26.0 & $4220 \pm 90$ \\
\hline 58 & 202765 & Wood charcoal & M04 & 8 & 9 & 12.751 & 3.377 & 0.513 & $3820 \pm 100$ & -25.7 & $4220 \pm 150$ \\
\hline 10 & 183570 & Wood charcoal & M06 & 7 & 9 & 12.916 & 5.269 & 0.495 & $3860 \pm 40$ & -25.5 & $4300 \pm 80$ \\
\hline 4 & 216517 & Wood charcoal & M06 & 4 & 4 & 12.761 & 5.253 & 0.871 & $3930 \pm 40$ & -24.9 & $4370 \pm 60$ \\
\hline 6 & 214129 & Wood charcoal & M06 & 5 & 6 & 12.356 & 5.309 & 0.780 & $3960 \pm 40$ & -26.7 & $4430 \pm 70$ \\
\hline 50 & 216521 & Wood charcoal & M04 & 4 & 3 & 12.088 & 3.455 & 0.947 & $4070 \pm 60$ & -25.0 & $4620 \pm 130$ \\
\hline 73 & 202768 & Wood charcoal & M04 & 11 & 16 & 12.574 & 3.867 & 0.154 & $4290 \pm 90$ & -25.7 & $4860 \pm 150$ \\
\hline 716 & 248893 & Wood charcoal & M05 & 25 & 29 & 12.579 & 4.448 & -0.798 & $8170 \pm 50$ & -25.2 & $9140 \pm 90$ \\
\hline 1764 & 410154 & Wood charcoal & M06 & 11 & $\mathrm{n} / \mathrm{a}$ & 12.995 & 5.296 & 0.132 & $8540 \pm 30$ & -26.5 & $9530 \pm 20$ \\
\hline 40 & 183571 & Wood charcoal & M06 & 20 & 24 & 12.870 & 5.858 & -0.513 & $8600 \pm 160$ & -25.0 & $9680 \pm 210$ \\
\hline 21 & 216519 & Wood charcoal & M06 & 14 & 18 & 12.763 & 5.059 & -0.005 & $8690 \pm 40$ & -26.2 & $9650 \pm 60$ \\
\hline 100 & 214133 & Wood charcoal & M06 & 24 & 29 & 12.267 & 5.861 & -0.763 & $8700 \pm 40$ & -26.0 & $9660 \pm 70$ \\
\hline 71 & 216522 & Wood charcoal & M04 & 12 & 15 & 12.520 & 3.591 & 0.060 & $8800 \pm 40$ & -26.3 & $9840 \pm 100$ \\
\hline 711 & 214134 & Wood charcoal & M06 & 24 & 29 & 12.795 & 5.591 & -0.824 & $8870 \pm 100$ & -24.1 & $9950 \pm 180$ \\
\hline 744 & 214140 & Wood charcoal & M06 & 28 & 34 & 12.070 & 5.503 & -1.152 & $8930 \pm 40$ & -25.2 & $10,060 \pm 100$ \\
\hline
\end{tabular}




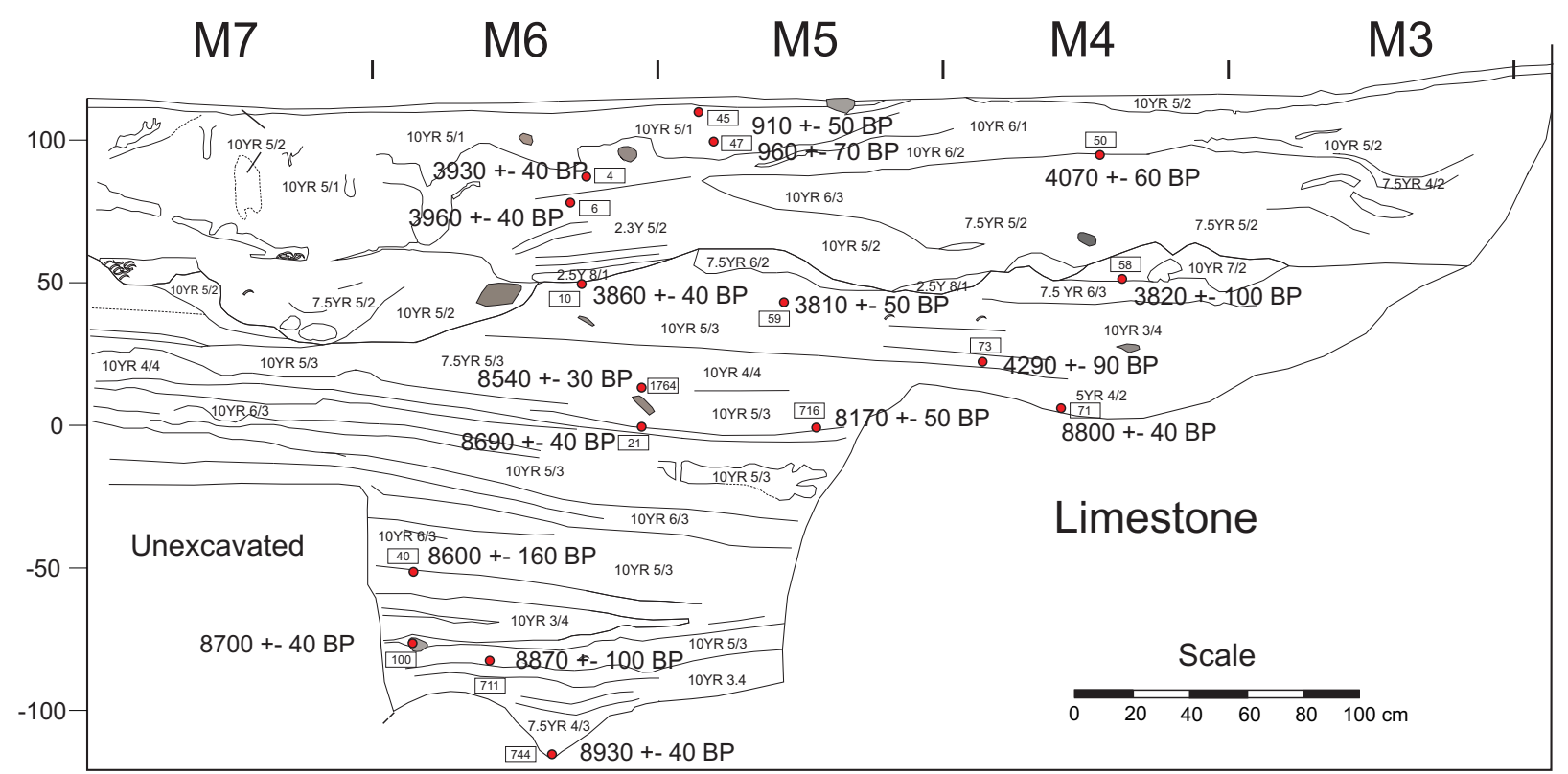

Figure 4 - East profile of the "M Units" showing major stratigraphic layers, soil colors, and radiocarbon samples.

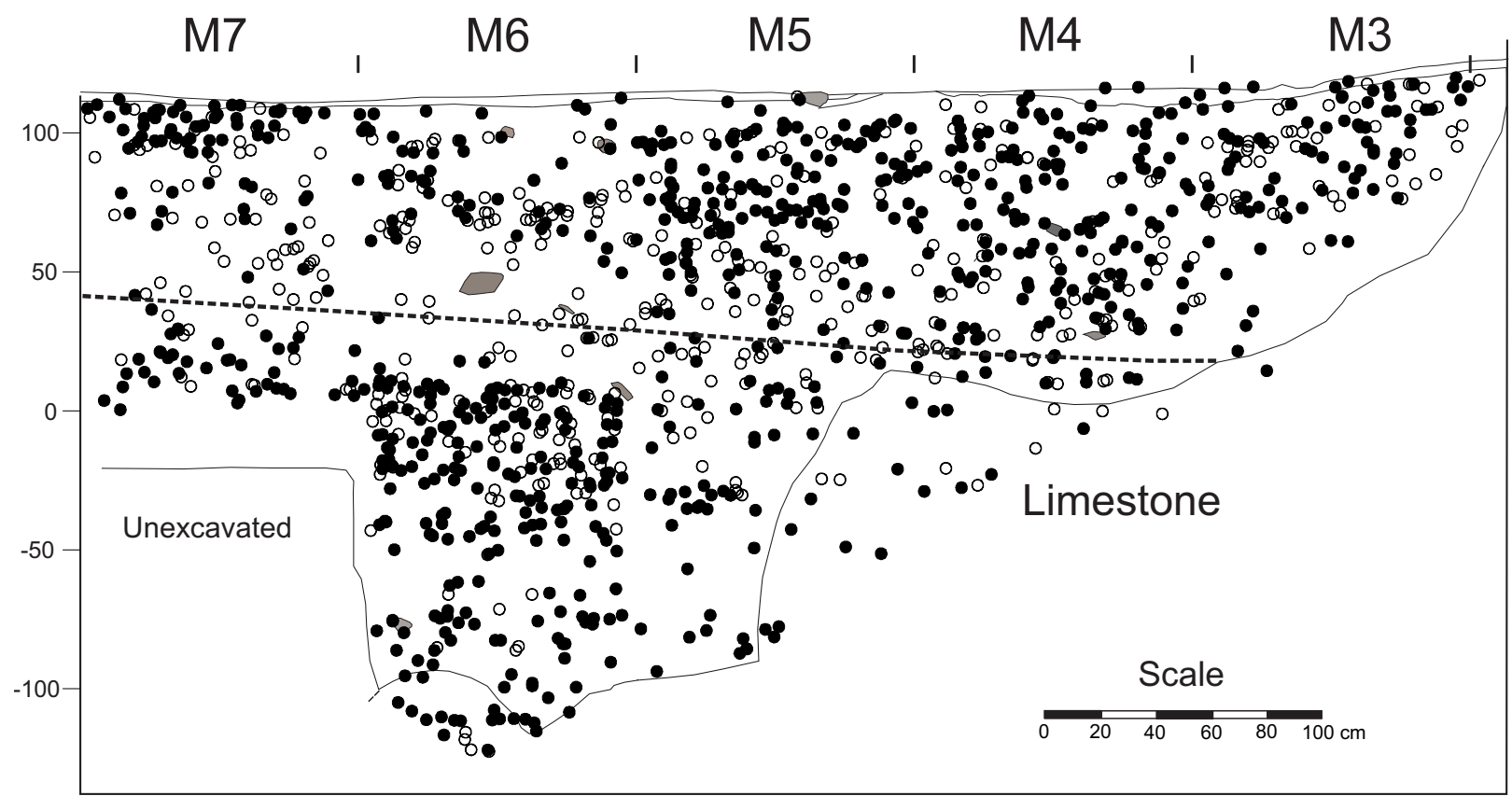

Figure 5 - Spatial arrangement of the lithics (black circles) and faunal (open circles) remains, backplotted against the East profile of the "M Units". Dotted line shows the approximate limit between early and middle Holocene as defined by the obtained ages.

Lapa de Taquaraçu (Araujo 2008, Araujo et al. 2012), where the strong ash production and the lack of significant natural sediment input resulted in a major stratigraphic and chronological hiatus that could not be recognized in the field. On the other hand, a third rockshelter, Lapa das Boleiras, showed a marked colluvial contribution that could be easily detected (Araujo et al. 2008). The spatial arrangement of the lithics and faunal remains in the $\mathrm{M}$ units is shown in Figure 5, and it can be 
perceived that the archaeological material occurs across the sequence without any spatial gaps.

It is important to note that the magnitude of accumulation of anthropogenic sediments observed in Lagoa Santa sites, and at Lapa do Santo in special is, in itself, a strong indicator of discreet cultural practices. Our present knowledge of Paleoindian sites in Eatern South America suggests that these practices were not operating elsewhere.

\section{LITHIC INDUSTRY}

The lithic industry at Lapa do Santo is well studied (Pugliese 2007, Moreno de Sousa 2014) and is very similar to the ones observed at other Paleoindian sites from Lagoa Santa, such as Lapa das Boleiras (Araujo and Pugliese 2010), Lapa de Taquaraçu (Araujo et al. 2012) as well as in several rockshelters (Beltrão 1975) and openair settings (Araujo et al. 2013, Bueno 2010). The industry can be characterized as the product of a generalized core technology (Teltser 1991), without formal artifacts. It was organized mainly around the flaking of quartz crystals, with the massive production of small flakes (mean length around $22 \mathrm{~mm}$-Figure 6), cores (Figure 7), and splinters. A small proportion of the resulting flakes (less than 1\%) were retouched. The raw material choice (small sized quartz crystals) is not related to availability, and probably reflects a strong cultural norm that is found through all rockshelters (Araujo et al. 2012) and Paleoindian open-air sites in the area (Sumidouro site; see Araujo et al. 2013, Coqueirinho site; see Bueno 2010). Quartz crystals do not appear in extensive outcrops at Lagoa Santa, but are abundant at Serra do Cipó, some $45 \mathrm{~km}$ towards East in a straight line. The hypothesis that the Lagoa Santa industry was based on a definite predilection for small quartz crystals, regardless of the abundance of good quality, larger raw materials in the area is supported by data coming from a much younger open-air lithic site named Lund, with an age of 2200 calBP (Araujo and Neves 2012) and located in close proximity to the already mentioned Paleoindian sites named Sumidouro and Coqueirinho. Lund site showed a completely different lithic industry and raw-material choice, with much larger artifacts, including (rare) formal ones, made on locally available flint and quartzite pebbles.

A sample of 759 lithic pieces from M units was analyzed for this study, including flakes, cores, utilized pebbles, polished stone, flaking debris, micro-flakes, and unmodified rawmaterials. Attributes used in this analysis comprise observations on raw-material type, type of blank (crystal, pebble, block) basic measurements (length, width and thickness) using a caliper, percentage of cortex observed in the flakes, type of bulb, number of dorsal flake scars, and overall number of flake scars (for cores).

\section{BONE INDUSTRY}

Artifacts made on modified bone appear at Lapa do Santo into three basic forms: flat-ended tipped artifacts ("spatulae"); pointed artifacts ("perforators"), and hooked artifacts ("fish-hooks"). Artifacts assigned to the first two classes are far more abundant, and were made mainly on cervid (Mazama sp.) metapodials (Figures 8 and 9). Their function, however, is still unknown. The relative frequencies of spatulae and perforators at Lapa do Santo, Lapa das Boleiras (Kipnis et al. 2010b), and Lapa de Taquaraçu are remarkably constant, with the three sites showing on average $70 \%$ of spatulae and 25\% of perforators (Santos 2011). Specifically at Lapa do Santo, a collection of 197 bone artifacts and fragments were analyzed. Due to the characteristics of the site, in this study we will concentrate on a smaller sample of 56 artifacts from units F/G- 12/13 and the $\mathrm{M}$ units, since in these areas we can couple stratigraphic integrity 

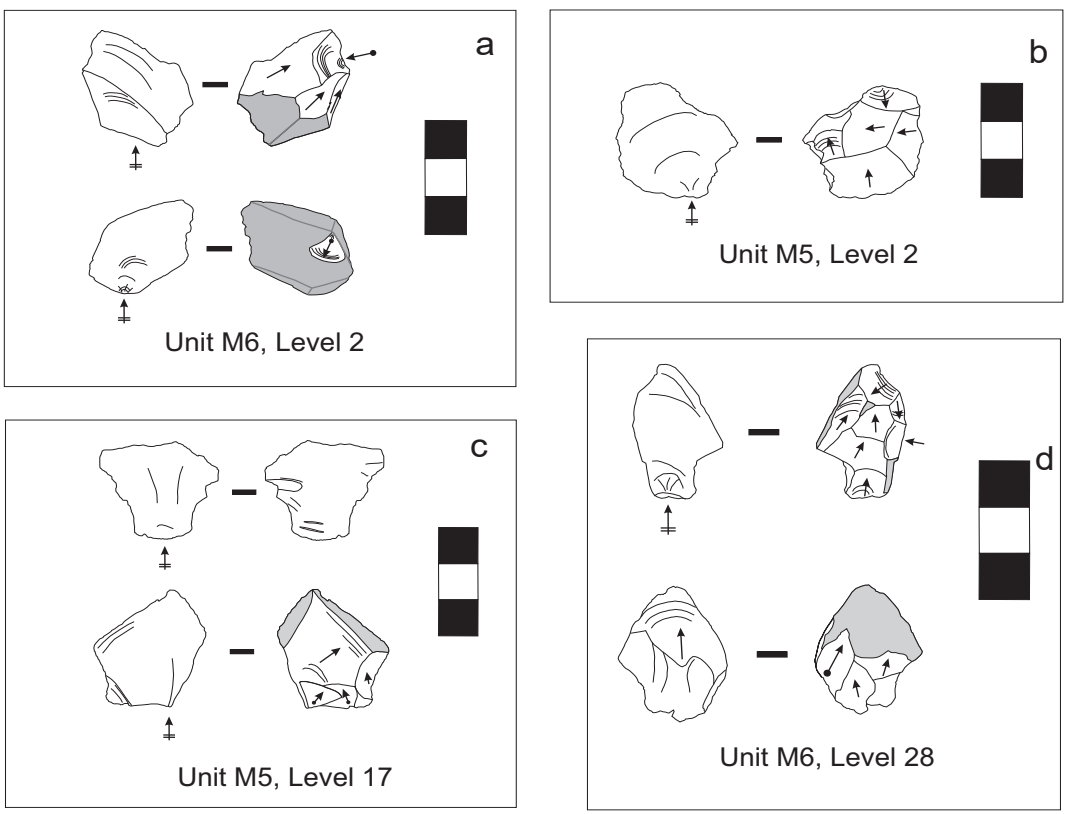

Figure 6 - Flakes found at different stratigraphic positions, all showing the same general technological characteristics. a: Flakes on quartz crystal, Level 2, later than 4200 cal BP; b: Flake on quartz crystal, Level 2, later than 4200 cal BP; c: Flake on quartz crystal, Level 17, ca. 9500 cal BP; d: Flakes on quartz crystal, Level 28, ca. 10,000 cal BP.
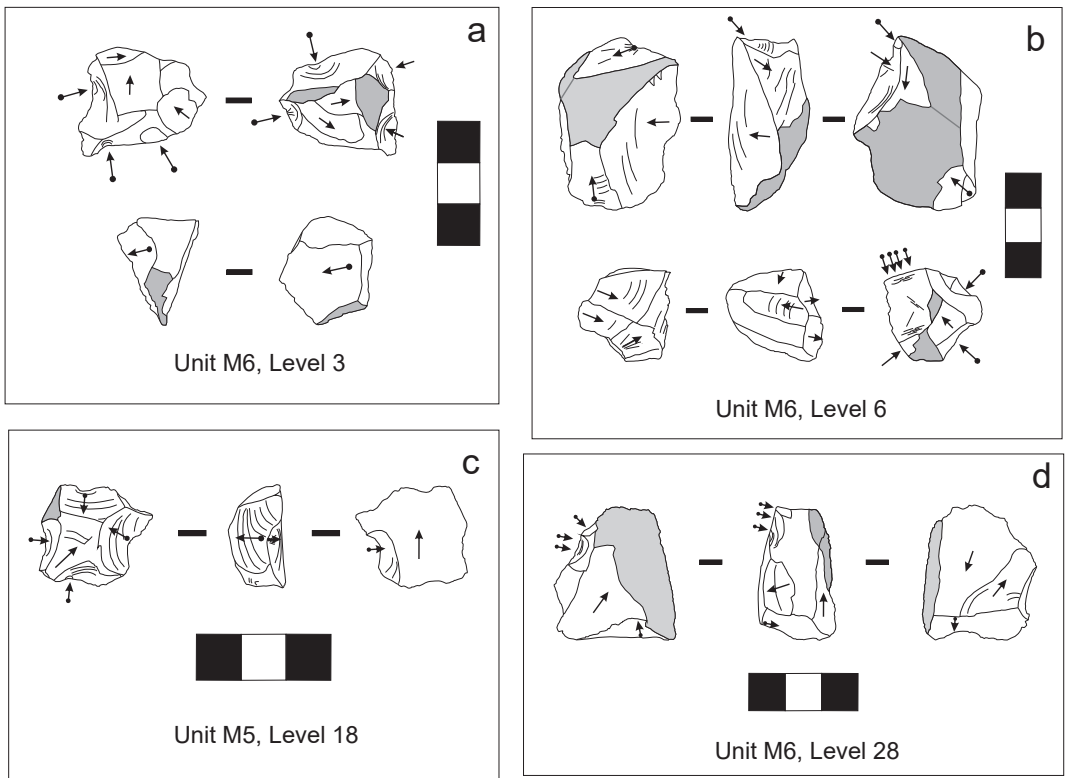

Figure 7 - Cores found at different stratigraphic positions, all showing the same general technological characteristics. a: Cores on quartz crystal, Level 3, later than 4200 cal BP; b: Cores on quartz crystal, Level 6, $4400 \mathrm{cal} \mathrm{BP}$; : Core on quartz crystal, Level 18, ca. 9500 cal BP; d: Core on flint, Level 28, ca. 10,000 cal BP. 


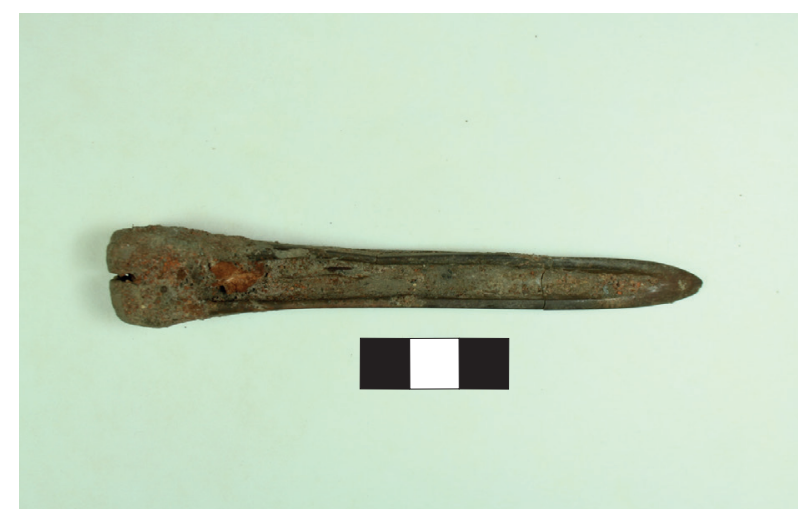

Figure 8 - Bone artifact ("spatula") found at Lapa do Santo. Piece St-3861/3862.

(no downslope movement) and chronological range (time span encompassing early to mid-Holocene).

\section{FAUNAL REMAINS}

The faunal remains from Lapa do Santo have been subject to preliminary analysis focusing on taphonomic and taxonomic studies of middle sized mammal remains (Bissaro Jr. 2008, Perez, 2009). The taphonomic analysis revealed no important differences between Lapa do Santo and another Paleoindian site from Lagoa Santa, Lapa das Boleiras, regarding the level of fragmentation of cervid (Mazama) bones (Bissaro Jr. 2008: 62, 64), although differences in the percentage of burned bones were observed (Bissaro Jr. 2008: 70). The study performed by Perez (2009) included information on chronology and some of her results will be discussed later. The preference for cervids (Mazama) and armadillos (Dasypus and Euphractus) described for Lapa do Santo has also been observed in Lapa das Boleiras (Kipnis et al. 2010a).

\section{RESULTS}

COMPARING THE EARLY VS. MIDDLE HOLOCENE ARCHAEOLOGICAL RECORD AT LAPA DO SANTO

We will now present the results of the statistical analysis performed for the stone and bone artifacts, as well zooarchaeological data previously

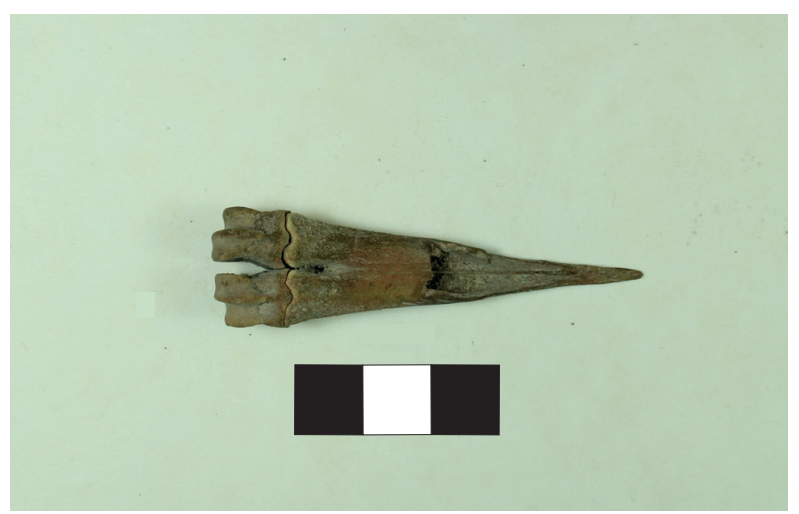

Figure 9 - Bone artifact ("perforator") found at Lapa do Santo. Piece St-2439.

published (Perez 2009), comparing the Early and Middle Holocene occupation at Lapa do Santo.

The Lithic Industry in the Early and Middle

\section{Holocene}

The analysis of the lithic industry aimed to understand if there were important changes through time. Due to the small sample size regarding some artifact classes observed in some levels, we divided the stratigraphic layers into two major groups: Early and Middle Holocene. This latter division took into account the radiocarbon dating associated with the layers.

The metric data was analyzed for complete flakes (Table II) and cores separately (Table III). Due to sample size constraints, we divided both samples in Early and Middle Holocene. A KruskalWallis tests showed no significant differences regarding length, width and thickness on both cores and flakes, except for flake width, which seems to be larger in the Early Holocene (p: 0.024). Since flake width is constrained by the size of crystal faces, this is probably an effect of the overexploitation of large crystals.

In order to understand if there were any important changes in terms of the pattern observed in the Early and the Middle Holocene, a z-test for 
TABLE II

Mean, Coefficient of Variation (CV) and mean rank of flake length, width and thickness from Middle Holocene $(\mathrm{MH}, \mathrm{n}=\mathbf{2 4 3})$ and Early Holocene $(\mathrm{EH}, \mathrm{n}=91)$.

\begin{tabular}{lcccccc}
\hline & $\begin{array}{c}\text { Mean } \\
\text { (MH) }\end{array}$ & $\begin{array}{c}\text { CV } \\
\text { (MH) }\end{array}$ & $\begin{array}{c}\text { Mean } \\
\text { (EH) }\end{array}$ & $\begin{array}{c}\text { CV } \\
\text { (EH) }\end{array}$ & $\begin{array}{c}\text { Mean } \\
\text { rank } \\
(\mathbf{M H})\end{array}$ & $\begin{array}{c}\text { Mean } \\
\text { rank } \\
(\mathbf{E H})\end{array}$ \\
\hline Lenght & 23.39 & 0.32 & 24.41 & 0.38 & 165.87 & 171.84 \\
Width & 20.32 & 0.38 & 22.18 & 0.38 & 160.21 & 186.96 \\
Thickness & 7.21 & 0.46 & 7.90 & 0.55 & 163.31 & 178.68 \\
\hline
\end{tabular}

TABLE IV

Number of elements, Z-test results (z score and $p$ value) and proportion between Middle Holocene (MH) and Early Holocene (EH) raw material types.

\begin{tabular}{|c|c|c|c|c|}
\hline & Quartz & $\begin{array}{l}\text { Hyaline } \\
\text { quartz }\end{array}$ & $\begin{array}{c}\text { Other } \\
\text { (Quartzite, } \\
\text { Milky quartz, } \\
\text { others) }\end{array}$ & Total \\
\hline $\begin{array}{l}\text { Early } \\
\text { Holocene }\end{array}$ & 142 & 63 & 22 & 227 \\
\hline $\begin{array}{l}\text { Middle } \\
\text { Holocene }\end{array}$ & 364 & 121 & 47 & 532 \\
\hline Total & 506 & 184 & 69 & 759 \\
\hline z score & 1.5696 & -1.4743 & -0.376 & \\
\hline $\mathrm{p}$ value & 0.11642 & 0.14156 & 0.70394 & \\
\hline $\begin{array}{l}\text { Proportion } \\
\mathrm{MH} / \mathrm{EH}\end{array}$ & $0.684 / 0.626$ & $0.227 / 0.278$ & $0.088 / 0.097$ & \\
\hline
\end{tabular}

the equality of two proportions was applied to flake and core attributes.

Raw material type was computed for all elements (flakes, cores, unmodified raw-material, polished stone, flaking debris, micro-flakes, utilized and flaked pebbles) except hammerstones. Table IV shows the sample size and type of raw material and presents the z-test results. No important differences were observed between samples, indicating that quartz, hyaline quartz and other raw materials were used in the same proportion throughout the Holocene.

Type of blank (crystal, pebble, other) was computed for all elements (flakes, cores, unmodified raw-material, polished stone, flaking
TABLE III

Mean, Coefficient of Variation (CV) and mean rank of core length, width and thickness from Middle Holocene $(\mathrm{MH}, \mathrm{n}=60)$ and Early Holocene $(\mathrm{EH}, \mathbf{n}=19)$.

\begin{tabular}{lcccccc}
\hline & $\begin{array}{c}\text { Mean } \\
\text { (MH) }\end{array}$ & $\begin{array}{c}\text { CV } \\
\text { (MH) }\end{array}$ & $\begin{array}{c}\text { Mean } \\
(\mathbf{E H})\end{array}$ & $\begin{array}{c}\text { CV } \\
\text { (EH) }\end{array}$ & $\begin{array}{c}\text { Mean } \\
\text { rank } \\
(\mathbf{M H})\end{array}$ & $\begin{array}{c}\text { Mean } \\
\text { rank } \\
(\mathbf{E H})\end{array}$ \\
\hline Lenght & 35.48 & 0.34 & 38.32 & 0.45 & 39.38 & 41.95 \\
Width & 26.15 & 0.40 & 27.58 & 0.47 & 39.73 & 40.87 \\
Thickness & 18.47 & 0.35 & 19.89 & 0.62 & 40.17 & 39.47 \\
\hline
\end{tabular}

TABLE V

Number of elements and Z-test results (z score and $p$ value) and proportion between Middle Holocene (MH) and Early Holocene (EH) types of blank.

\begin{tabular}{|c|c|c|c|c|}
\hline & Crystal & Pebble & Other & Total \\
\hline Early & 142 & 13 & 72 & \\
\hline Holocene & & & & 227 \\
\hline Middle & 307 & 51 & 174 & \\
\hline Holocene & & & & 532 \\
\hline Total & 449 & 64 & 246 & 759 \\
\hline$Z$ score & -1.2442 & 1.7521 & 0.2665 & \\
\hline$P$ value & .21498 & 0.08012 & 0.78716 & \\
\hline Proportion & & & & \\
\hline $\mathrm{MH} / \mathrm{EH}$ & $0.577 / 0.626$ & $0.096 / 0.057$ & $0.327 / 0.317$ & \\
\hline
\end{tabular}

debris, micro-flakes, utilized and flaked pebbles) except hammerstones. Table V shows the sample size and type of blank and the z-test results. The lack of important differences observed among samples indicates a continuity in the type of blank proportions from the Early to the Middle Holocene.

The overall number of flake scars observed in cores, the sample size, and the z-test results are presented in Table VI. No significant differences were detected between samples, attesting a constancy in the proportion of the number of scars from Early and Middle Holocene cores.

The bulb type, sample size, and z-test results are presented in Table VII. The z-test results indicate no important differences regarding proportions of bulb type in the analysed sample.

The amount of observed cortex in flakes, the sample size and the z-test results are presented in 


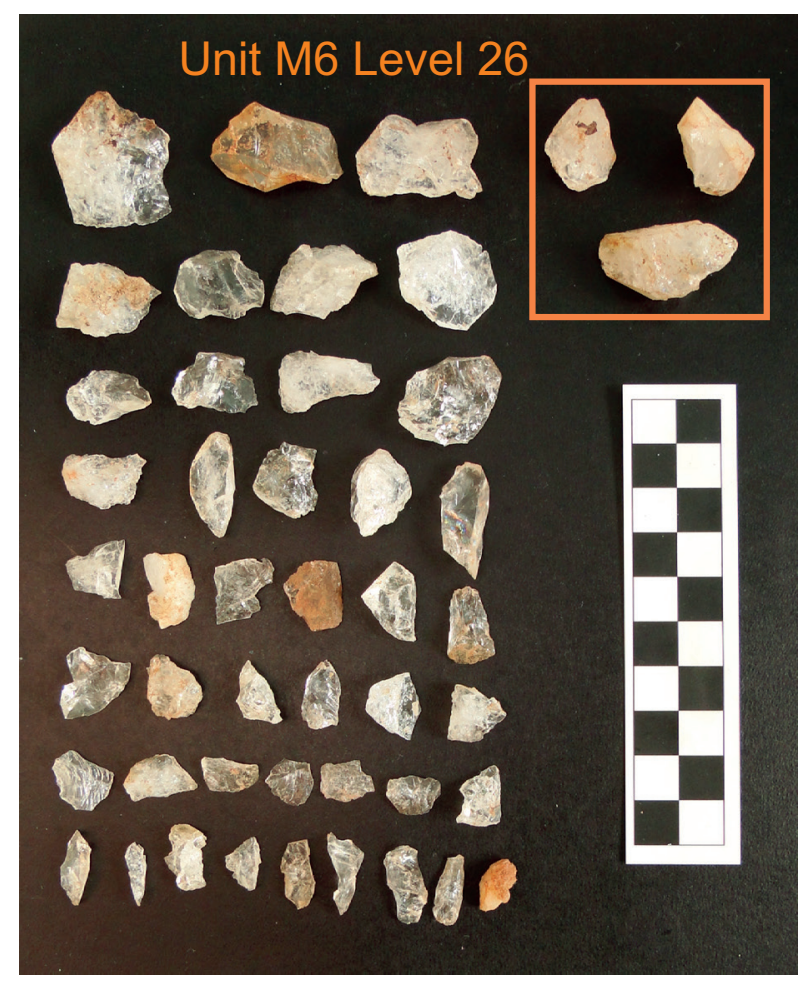

Figure 10 - Sample of cores (inside box) and flakes from Unit M6, Level 26, dated ca. 10,000 cal BP.

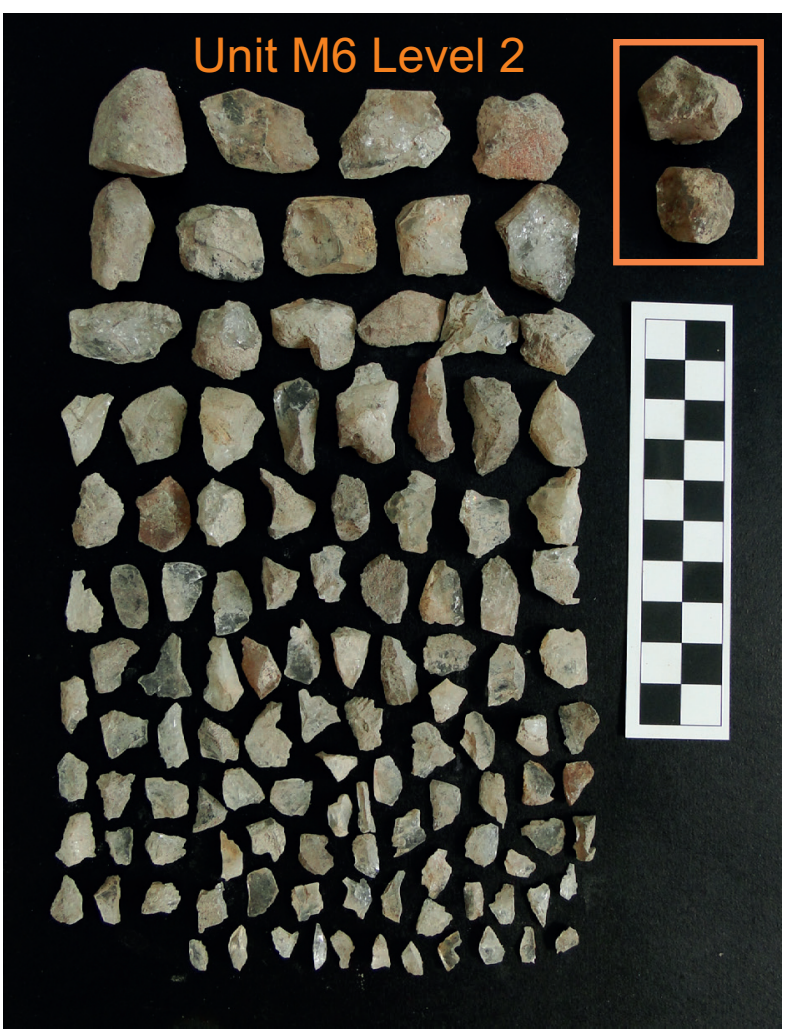

Figure 12 - Sample of cores (inside box) and flakes from Unit M6, Level 2, later than 4200 cal BP.

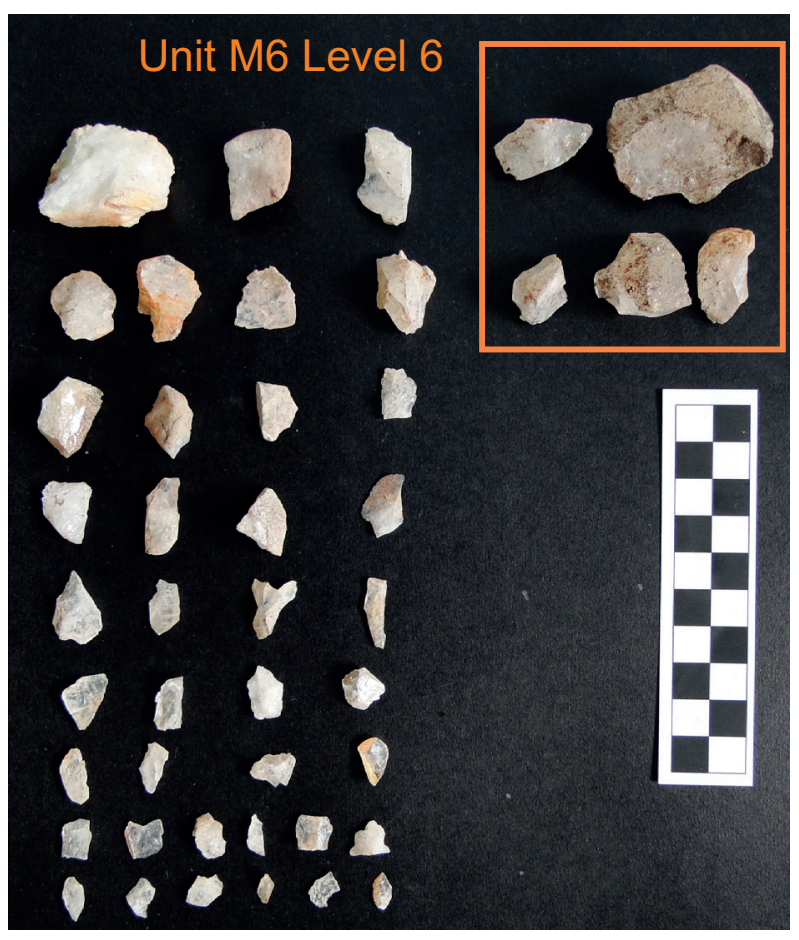

Figure 11 - Sample of cores (inside box) and flakes from Unit M6, Level 6, dated ca. 4400 cal BP.

Table VIII. No important differences were observed among samples, indicating a lack of change in the proportions of the amount of cortex in flakes through the Holocene.

To finish our analysis, the number of dorsal scars in flakes, the sample size, and the z-test results are presented in Table IX. Again, no important differences were observed between the Early and Middle Holocene samples, pointing to a lack of change in the proportion vis-à-vis the number of dorsal scars in flakes.

As a mean of showing graphically the similarity of the industry, Figures 10,11 and 12 present a sample of cores and flakes from three stratigraphic contexts: a lower, early Holocene assemblage (Level 26, ca. 10,000 cal BP), an intermediate, middle Holocene assemblage (Level 6, ca. $4400 \mathrm{cal}$ BP), and an upper, middle Holocene assemblage (Level 2, later than 4200 cal BP). 
TABLE VI

Number of analysed cores, number of scars, Z-test results (z score and p value) and proportion between Middle Holocene (MH) and Early Holocene (EH).

\begin{tabular}{lccccc}
\hline Flake scars number & 1 & 2 & 3 & Total \\
\hline Early Holocene & 1 & 2 & 5 & 11 & 19 \\
Middle Holocene & 7 & 7 & 7 & 12 & 39 \\
Total & 8 & 0.1363 & -1.5504 & 50 & 79 \\
\hline Z score & 0.8063 & 0.88866 & 0.12114 & 0.56 & 0.57548 \\
P value & 0.41794 & $0.117 / 0.105$ & $0.117 / 0.263$ & $0.650 / 0.579$ \\
Proportion MH/EH & $0.117 / 0.053$ & & \\
\hline
\end{tabular}

TABLE VII

Bulb types from Early and Middle Holocene Holocene flakes.

\begin{tabular}{|c|c|c|c|c|c|c|}
\hline & Salient & Diffuse & Carinated & Absent & Undetermined & Total \\
\hline Early Holocene & 48 & 32 & 3 & 38 & 1 & 74 \\
\hline Middle Holocene & 116 & 79 & 7 & 97 & 4 & 187 \\
\hline Total & 164 & 111 & 10 & 135 & 5 & 261 \\
\hline Z score & -0.2032 & -0.0333 & -0.0915 & 0.1734 & 0.4329 & \\
\hline $\mathrm{P}$ value & 0.84148 & 0.97606 & 0.92828 & 0.86502 & 0.6672 & \\
\hline Proportion MH/EH & $0.383 / 0.393$ & $0.261 / 0.262$ & $0.023 / 0.025$ & $0.32 / 0.311$ & $0.013 / 0.008$ & \\
\hline
\end{tabular}

TABLE VIII

Amount of cortex, Z-test results (z score and p value) and proportion between Middle Holocene (MH) and Early Holocene (EH) flakes.

\begin{tabular}{|c|c|c|c|c|c|}
\hline & Absent & $<50 \%$ & $>50 \%$ & $100 \%$ & Total \\
\hline Early Holocene & 24 & 42 & 19 & 6 & 91 \\
\hline Middle Holocene & 79 & 104 & 47 & 19 & 249 \\
\hline Total & 103 & 146 & 66 & 25 & 340 \\
\hline Z score & 0.951 & -0.7235 & -0.4135 & 0.3244 & \\
\hline$P$ value & 0.34212 & 0.47152 & 0.6818 & 0.74896 & \\
\hline Proportion $\mathrm{MH} / \mathrm{EH}$ & $0.317 / 0.264$ & $0.418 / 0.462$ & $0.189 / 0.209$ & $0.076 / 0.066$ & \\
\hline
\end{tabular}

TABLE IX

Number of dorsal scars, Z-test results (z score and p value) and proportion between Middle Holocene (MH) and Early Holocene (EH) flakes.

\begin{tabular}{lccccccc}
\hline & Zero & 1 & 2 & 3 & $>=4$ & $\begin{array}{c}\text { Not } \\
\text { recorded }\end{array}$ & Total \\
\hline Early Holocene & 8 & 20 & 23 & 17 & 18 & 5 & 91 \\
Middle Holocene & 23 & 49 & 64 & 67 & 42 & 4 & 249 \\
Total & 31 & 69 & 87 & 84 & 60 & 9 & 340
\end{tabular}

\begin{tabular}{lccccc} 
& Zero & 1 & 2 & 3 & $>=4$ \\
\hline$Z$ score & 0.1264 & -0.4667 & 0.0801 & 1.5571 & -0.6237 \\
P value & 0.89656 & 0.63836 & 0.93624 & 0.11876 & 0.53526 \\
Proportion & $0.092 / 0.088$ & $0.197 / 0.220$ & $0.257 / 0.253$ & $0.269 / 0.187$ & $0.169 / 0.198$ \\
MH/EH & & & &
\end{tabular}


TABLE X

Number of bone perforators and spatulae found in Lapa do Santo (MH: Middle Holocene, EH: Early Holocene).

\begin{tabular}{ccccc}
\hline $\begin{array}{c}30 \mathbf{c m} \\
\text { levels }\end{array}$ & Perforators & Spatulae & Cal Age BP & Period \\
\hline A & 3 & 0 & & MH* \\
B & 5 & 3 & 4620 & MH \\
C & 2 & 2 & 4510 & MH \\
D & 4 & 6 & 8810 & EH \\
E & 0 & 2 & & EH \\
F & 3 & 5 & 9900 & EH \\
G & 1 & 5 & & EH \\
H & 0 & 0 & & EH \\
I & 2 & 4 & & EH \\
J & 1 & 4 & & EH \\
K & 0 & 3 & 10060 & EH \\
L & 0 & 1 & 9940 & EH \\
\hline
\end{tabular}

*This level contains some very late ages (880 BP), but they are probably related to the episodic use of the rockshelter by ceramist groups. We do not consider the stone and bone artifacts related to these late occupants.

TABLE XI

Absolute and relative (\%) abundance of taxa calculated from NISP and MNI, for the Early and Middle Holocene levels. NUSP: Number of Unidentifiable Specimens, after Perez (2009).

\begin{tabular}{llcc}
\hline Early & Taxon & $\begin{array}{c}\text { NISP } \\
\text { (absolute } \\
\text { abundance } \\
\text { / relative } \\
\text { abundance) }\end{array}$ & $\begin{array}{c}\text { MNI } \\
\text { (absolute } \\
\text { abundance } \\
\text { / relative } \\
\text { abundance) }\end{array}$ \\
\cline { 2 - 3 } & Carnivore & $4 / 0,42$ & $1 / 1,67$ \\
& Primate & $3 / 0,32$ & $1 / 1,67$ \\
Chelonia & $6 / 0,63$ & $1 / 1,67$ \\
Reptile & $54 / 5,68$ & $4 / 6,67$ \\
Fish & $127 / 13,35$ & $5 / 8,33$ \\
$\begin{array}{l}\text { Dasypus } \\
\text { novemcinctus }\end{array}$ & $31 / 3,26$ & $4 / 6,67$ \\
Marsupial & $13 / 1,37$ & $4 / 6,67$ \\
Euphractus & $6 / 0,63$ & $1 / 1,67$ \\
sexcintus & $33 / 3,47$ & $4 / 6,67$ \\
Bird & $4 / 0,42$ & $1 / 1,67$ \\
Silvylagus & $129 / 13,56$ & $23 / 38,33$ \\
brasiliensis & Small rodents & & \\
\hline
\end{tabular}

TABLE XI (continuation)

\begin{tabular}{|c|c|c|c|}
\hline & Taxon & $\begin{array}{c}\text { NISP } \\
\text { (absolute } \\
\text { abundance } \\
\text { / relative } \\
\text { abundance) }\end{array}$ & $\begin{array}{c}\text { MNI } \\
\text { (absolute } \\
\text { abundance } \\
\text { / relative } \\
\text { abundance) }\end{array}$ \\
\hline & Amphibia & $55 / 5,78$ & $5 / 8,33$ \\
\hline & Tayassu sp. & $10 / 1,05$ & $1 / 1,67$ \\
\hline & $\begin{array}{l}\text { Cuniculus } \\
\text { paca }\end{array}$ & $6 / 0,63$ & $1 / 1,67$ \\
\hline & Mazama sp. & $137 / 14,41$ & $4 / 6,67$ \\
\hline & NUSP & $333 / 35,02$ & --- \\
\hline Total & 15 & $951 / 100$ & $60 / 100$ \\
\hline \multirow[t]{16}{*}{$\begin{array}{l}\text { Middle } \\
\text { Holocene }\end{array}$} & Carnivore & $2 / 0,48$ & $1 / 2,22$ \\
\hline & Primate & $4 / 0,97$ & $2 / 4,44$ \\
\hline & Chelonia & $5 / 1,21$ & $1 / 2,22$ \\
\hline & Reptile & $26 / 6,30$ & $4 / 8,89$ \\
\hline & Fish & $56 / 13,56$ & $6 / 13,33$ \\
\hline & $\begin{array}{l}\text { Dasypus } \\
\text { novemcinctus }\end{array}$ & $15 / 3,63$ & $2 / 4,44$ \\
\hline & Marsupial & $11 / 2,66$ & $3 / 6,67$ \\
\hline & $\begin{array}{l}\text { Euphractus } \\
\text { sexcintus }\end{array}$ & $1 / 0,24$ & $1 / 2,22$ \\
\hline & Bird & $17 / 4,12$ & $3 / 6,67$ \\
\hline & $\begin{array}{l}\text { Silvylagus } \\
\text { brasiliensis }\end{array}$ & $7 / 1,69$ & $1 / 2,22$ \\
\hline & Small rodents & $48 / 11,62$ & $7 / 15,56$ \\
\hline & Amphibia & $43 / 10,41$ & $9 / 20,00$ \\
\hline & Tayassu sp. & $1 / 0,24$ & $1 / 2,22$ \\
\hline & $\begin{array}{l}\text { Cuniculus } \\
\text { paca }\end{array}$ & $9 / 2,18$ & $1 / 2,22$ \\
\hline & Mazama sp. & $68 / 16,46$ & $3 / 6,67$ \\
\hline & NUSP & $100 / 24,21$ & --- \\
\hline Total & 15 & $413 / 100$ & $45 / 100$ \\
\hline
\end{tabular}

Bone Industry in the Early and Middle Holocene

Table X presents the number of perforators and spatulae observed in each $30 \mathrm{~cm}$ level and the calibrated dates when available. Due to the small sample size, data was reorganized and Chi-square tests were applied, first in a $2 \times 2$ table (Early and Middle Holocene, Chi-square: 7.4363, p: 0.006392) and then dividing the Early Holocene in two parts, 
TABLE XII

Test ts comparing the relative abundances (NISP and MNI) of Middle Holocene (MH) and Early Holocene (EH) taxa (classified as genus or species) after Perez (2009).

\begin{tabular}{|c|c|c|}
\hline Taxon & $\%$ NISP & $\% \mathrm{MNI}$ \\
\hline Mazama sp. & $\begin{array}{c}\mathrm{MH}=\mathrm{EH} \\
(\mathrm{ts}=1,0 ; \mathrm{p}=0,33)\end{array}$ & $\begin{array}{c}\mathrm{MH}=\mathrm{EH} \\
(\mathrm{ts}=0,0 ; \mathrm{p}=1,00)\end{array}$ \\
\hline Cuniculus paca & $\begin{array}{c}\mathrm{MH}>\mathrm{EH} \\
(\mathrm{ts}=2,3 ; \mathrm{p}=0,02)\end{array}$ & $\begin{array}{c}\mathrm{MH}=\mathrm{EH} \\
(\mathrm{ts}=0,2 ; \mathrm{p}=0,84)\end{array}$ \\
\hline $\begin{array}{l}\text { Silvylagus } \\
\text { brasiliensis }\end{array}$ & $\begin{array}{c}\mathrm{MH}>\mathrm{EH} \\
(\mathrm{ts}=2,2 ; \mathrm{p}=0,03)\end{array}$ & $\begin{array}{c}\mathrm{MH}=\mathrm{EH} \\
(\mathrm{ts}=0,2 ; \mathrm{p}=0,84)\end{array}$ \\
\hline Tayassu sp. & $\begin{array}{c}\mathrm{MH}>\mathrm{EH} \\
(\mathrm{ts}=1,8 ; \mathrm{p}=0,07)\end{array}$ & $\begin{array}{c}\mathrm{MH}=\mathrm{EH} \\
(\mathrm{ts}=0,2 ; \mathrm{p}=0,84)\end{array}$ \\
\hline $\begin{array}{l}\text { Euphractus } \\
\text { sexcintus }\end{array}$ & $\begin{array}{c}\mathrm{MH}=\mathrm{EH} \\
(\mathrm{ts}=1,0 ; \mathrm{p}=0,30)\end{array}$ & $\begin{array}{c}\mathrm{MH}=\mathrm{EH} \\
(\mathrm{ts}=0,2 ; \mathrm{p}=0,84)\end{array}$ \\
\hline $\begin{array}{l}\text { Dasypus } \\
\text { novemcinctus }\end{array}$ & $\begin{array}{c}\mathrm{MH}=\mathrm{EH} \\
(\mathrm{ts}=0,3 ; \mathrm{p}=0,73)\end{array}$ & $\begin{array}{c}\mathrm{MH}=\mathrm{EH} \\
(\mathrm{ts}=0,5 ; \mathrm{p}=0,62)\end{array}$ \\
\hline
\end{tabular}

one composed by levels $\mathrm{D}$ to $\mathrm{G}$ and another by levels H to L (Chi-square: 7.907, p: 0.019187). Both results were significant at $\mathrm{p}<0.05$, indicating a greater emphasis on the production of spatulae in the Early Holocene.

\section{Subsistence Across Time: Faunal Remains}

The analysis of the faunal remains of Lapa do Santo was made by Perez (2009), and several of the specimens came from the M Units. The author compared data from the Early, Middle, and Late Holocene, but for our purposes only the Early and Middle datasets will be used. Table XI shows the MNI / NISP for the two periods, and Table XII compares the relative abundances (NISP and $\mathrm{MNI}$ ) of both periods for taxa identified at genus or species level. The ts test results show a remarkable constancy in the proportions of hunted animals, especially for the most represented taxa, such as cervids (Mazama) and armadillos (Dasypus and Euphractus). The absolute abundance of complete skeletal elements of taxa classified as genus or species for the Middle and Early Holocene levels (Table XIII) presented no clear differences between the two periods (see also Mingatos and Okumura 2016). Due to the small sample size, Chi Square
TABLE XIII

\begin{tabular}{|c|c|c|}
\hline \multicolumn{3}{|c|}{$\begin{array}{l}\text { Absolute abundance of complete skeletal elements of taxa } \\
\text { classified as genus or species for the Early and Middle } \\
\text { Holocene levels, after Perez (2009). }\end{array}$} \\
\hline \multicolumn{3}{|c|}{ Early Holocene $\quad$ Middle Holocene } \\
\hline Mazama sp. & \multicolumn{2}{|c|}{ Mazama sn } \\
\hline $\begin{array}{l}\text { Cuniculus } \\
\text { paca }\end{array}$ & 0 & 2 \\
\hline $\begin{array}{l}\text { Silvylagus } \\
\text { brasiliensis }\end{array}$ & 0 & 1 \\
\hline Tayassu sp. & 0 & 0 \\
\hline $\begin{array}{l}\text { Euphractus } \\
\text { sexcintus }\end{array}$ & 3 & 1 \\
\hline $\begin{array}{l}\text { Dasypus } \\
\text { novemcinctus }\end{array}$ & 4 & 3 \\
\hline
\end{tabular}

tests and/or Fisher tests were performed only for Mazama (Chi Square: 0.2864, p: 0,59256; Fisher test: 0,734276, not significant) and Dasypus (Fisher: 1 , not significant), pointing to a lack of significant differences between the levels of fragmentation of skeletal elements from Early and Middle Holocene.

\section{DISCUSSION}

Our data suggests the maintenance across time of a very specific set of material culture that includes lithic and bone industries, subsistence practices, and the strong accumulation of anthropogenic sediment. This set of material culture is both formally and technologically unrelated to other known contemporaneous archaeological traditions (such as Umbu and Itaparica, Figure 1; Lourdeau 2015, Moreno de Sousa 2016, 2017, Okumura and Araujo 2016), and its persistence in time can be best explained by the presence of a single line of cultural transmission, or a cultural phylogeny. The most parcimonious explanation involves the operation of a very stable cultural transmission process, resulting in a cultural tradition in its most exact sense, or "patterned ways of doing things that exist in identifiable form over extended periods of time" (O'Brien et al. 2010:3797). As discussed 

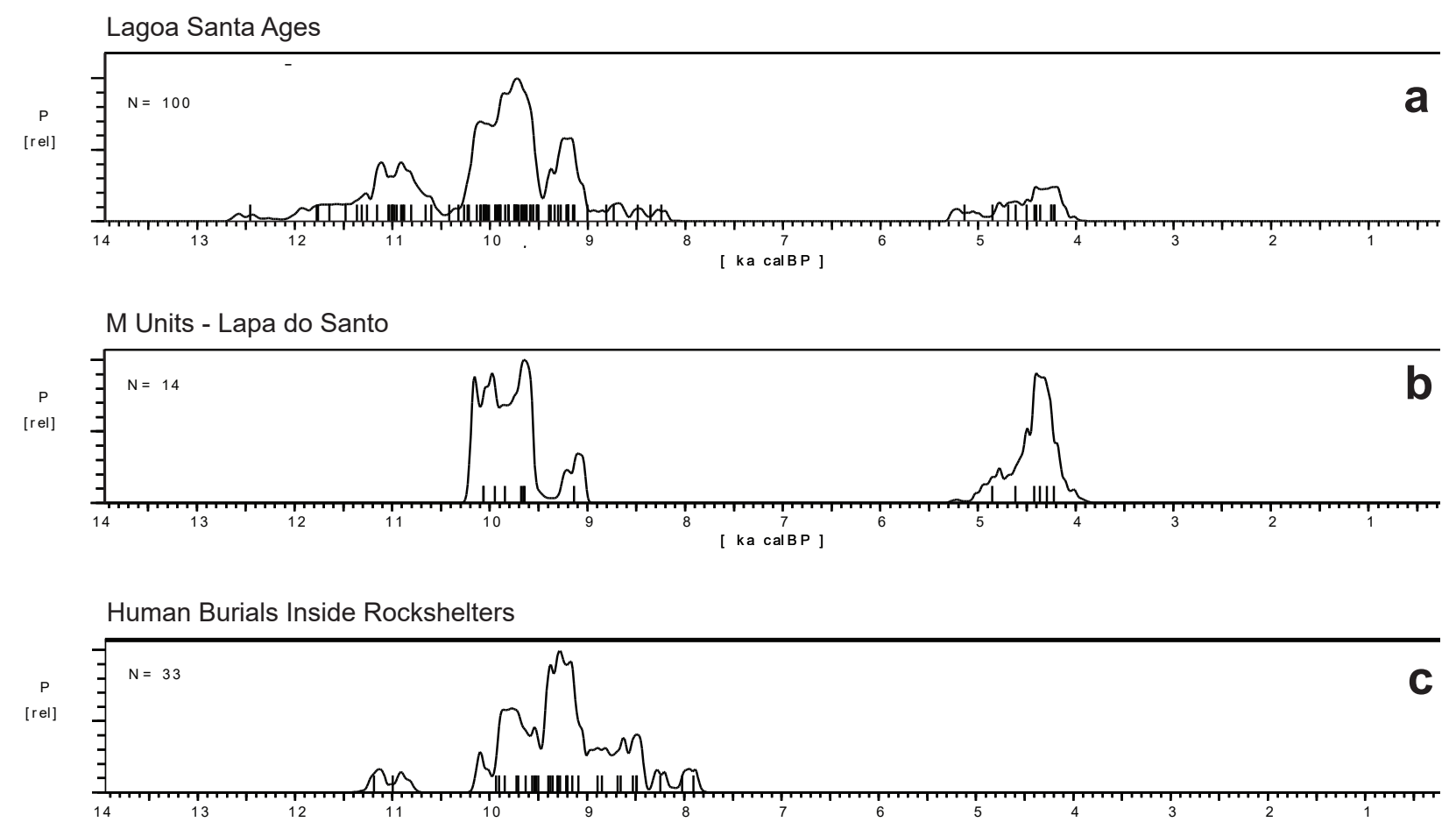

Figure 13 - Summed radiocarbon probability distribution curves for Lagoa Santa region. a: Consolidated data for the whole region; b: Ages obtained for charcoal in the "M Units"; c: Ages obtained for human burials inside several rockshelters.

elsewhere (Okumura and Araujo 2014), according to the theoretical expectations of Evolutionary Archaeology, the persistence of cultural traits over such a long period of time can only be accounted for in situations where a strong cultural norm was operating, or what could be called a "metatradition" (Palmer 2010). The situations in which extreme cultural persistence can be advantageous involve environmental stability (which seems to be the case in Southern Brazil, see Okumura and Araujo 2014). By environment we mean not only the natural setting, with its soil, plants, animals and precipitation regimes, but also other human groups that happen to be in neighboring regions, or even in the same region. Given stable external conditions, the operation of a meta-tradition is a way of avoiding cultural change that could be potentially harmful (VanPool and Savage 2010).

However, Lagoa Santa also presents a very important clue as to the manner in which people tend to cope with environmental changes. Contrary to what can be observed in the Paleoindian record of Southern Brazil (the Umbu Tradition, Figure 1 - see Okumura and Araujo 2014), the occupation of the territory by the Lagoa Santa Paleoindians was not continuous. As we mentioned earlier, mirroring the occupational gap at Lapa do Santo (Figure 13b), there is a major hiatus in the occupation of Lagoa Santa region as a whole, spanning 3200 years (Figure 13a). The causes for this abandonment are most probably related to climatic reasons (Araujo et al 2005, Raczka et al. 2013). When people moved back to Lagoa Santa, in the Middle Holocene, they not only chose the same area their forebears occupied intensively, but also the same rockshelters, and they brought back the same material culture. This suggests a strategy that involved a geographic change in the focal area of occupation, while maintaining the cultural structure virtually untouched, including the oral 
tradition that should be involved in the recognition and periodic visits to the rockshelters as places to be remembered, throughout an absence of intense occupation that lasted 160 generations.

In spite of the stable subsistence strategy and the overall homogenous aspect of the Lagoa Santa lithic industry, it is possible to perceive some trends across time during the early Holocene occupation of the rockshelters. The more conspicuous can be perceived in the human burial patterns. The area was occupied since 12,500 calBP $\left(10,490{ }^{14} \mathrm{C}\right.$ years BP, Figure 13a), but the widespread practice of burying people inside the rockshelters appears only about 9900 calBP $\left(8830{ }^{14} \mathrm{C}\right.$ years BP $)$, or 2500 years after the first occupation (Figure 13c).

Another change can be perceived in the higher frequency of flint in the lower stratigraphic layers, that are not represented in the M Units. Even though flint represents only $5 \%$ of the raw materials present at Lapa do Santo and Lapa das Boleiras (Pugliese 2007), more than $90 \%$ of the pieces made on flint appear in the interval between 12,500 and 10,200 calBP $\left(10,490\right.$ and $9,000{ }^{14} \mathrm{C}$ years BP $)$. It is important to note that this change is only related to the raw materials, and not to the technology itself. In spite of the very good quality of the flint, this raw material was being flaked in the same manner as the quartz crystals (Figure 7d). Finally, there is also a small change regarding the frequencies of the bone artifacts. While the upper layers present larger quantities of pointed artifacts ("perforators"), the lower layers show larger frequencies of flatpointed bone artifacts ("spatulae"). However, even this change does not seem to be significant in cultural terms, since the exact opposite pattern was observed at Lapa das Boleiras rockshelter (Araujo 2010:217).

Since these changes were set by the end of the early Holocene occupation, the "jump" to the middle Holocene showed no major cultural differences. Both the lithics and the faunal remains frequencies showed no significant changes. Again, even taking into consideration these (slight) differences in frequency of artifacts and raw materials during the early Holocene, the most remarkable aspect of the Lagoa Santa Paleoindians is their extreme cultural persistence.

\section{CONCLUSIONS}

The case of Lagoa Santa is the second instance of the same phenomenon already observed in another South American Paleoindian group that was culturally unrelated (Umbu Tradition - Figure 1), but that nevertheless also showed an extreme cultural persistence (Okumura and Araujo 2014). We tend to explain this as a convergence that points towards an understanding of cultural processes that is at odds with the common view that cultural change in behaviorally modern humans is necessarily fast. Given a relatively stable environment, large territories to move around, and (in all probability) a relatively low population, these Eastern South American Paleoindians seemed to maintain their cultural structure for extremely long time spans. If we take into account the total time span in which Lagoa Santa Tradition can be recognized as such, we will reach the impressive number of 8240 years, or roughly 412 generations (Figure 13a). It is important to note that, in the case of Lagoa Santa, a shift in the environmental conditions did not trigger cultural change (cf. Hiscock 1994, 2002, Rowland 1999), or cultural collapse (cf. Binford et al. 1997), but only a geographic displacement with the full maintenance of the material culture. As put by Henrich (2010:108-109): "when faced with population pressure, environment shifts, or external threats, people do sometimes innovate; however, more often they emigrate, suffer and/or die".

Our data also suggests that the cultural attributes more directly related to subsistence were maintained virtually untouched, whereas ritual aspects, in the form of mortuary practices, showed 
significant changes. This supports a materialist approach of the Paleoindian behavior, that can be subsumed under concepts like "culture core", proposed long ago by Steward (1963:37).

Another important factor to take into account is that the persistence of cultural traits is not necessarily the "best strategy" in evolutionary terms, but can be simply the outcome of low population / low interconnectedness between individuals. There is a growing literature dealing with the relationship between population size and rates of cultural innovation and cultural change (Henrich 2004, 2010, Neiman 1995, Shennan 2000, 2001), and the fact the two different Paleoindian groups presented the same characteristics can be related to somewhat lower population / interconnectedness when compared to other parts of the world in the same period, including North America. For instance, when we take into account the archaeological record left by Holocene huntergatherers in North America, the profusion of artifact types after the (short) Clovis and Folson periods is overwhelming, with thousands of different bifacial point shapes occurring in very short time spans and neighboring areas (Justice 1995, 2002, Huckell 1996). This suggests higher rates of cultural change, the reasons for which should be investigated. We can advance some possibilities related to the geographic position of the northern portion of the continent and its possible cultural links to both Asia (Goebel et al. 2008, Goebel 2013) and Europe (Bradley e Stanford 2004, Stanford e Bradley, 2012), and higher population numbers in North America when compared to South America, resulting in more innovation rates per se. If this demographic difference is coupled with higher climatic variability in parts of North America during the Holocene (e.g., Anderson et al. 2007, Kennett et al. 2007), the outcome would be a lack of territorial pliability, which would prevent some human groups from adopting the strategy of moving into a new area while maintaining their cultural standards.

In sum, we believe that the Eastern South American early and middle Holocene archaeological record shows two very compelling cases of what happens in cultural terms when human groups are freed from major environmental (i.e., social + climatic) stress: they will strive to continue doing what they always did.

\section{ACKNOWLEDGMENTS}

We would like to thank Walter Neves, Luís B. Piló, Renato Kipnis, and Danilo Bernardo for their major contribution to this work. To Cassiana Pursino Perez, for making available unpublished data, and to Eliane Chim for the pictures of the bone industry. To José Hein, for supporting the research and granting access to Lapa do Santo site. This research was financially supported by Fundação de Amparo à Pesquisa do Estado de São Paulo (FAPESP), projects 1999/00670-7, 2004/01321-6, 2006/52188 and Conselho Nacional de Desenvolvimento Científico e Tecnológico (CNPq), projects 300818/2007-6, 472535/2007-2, 300339/2008-9, and 303566/2014-0.

\section{REFERENCES}

ANDERSON DG, RUSSO M AND SASSAMAN K. 2007. Mid-Holocene cultural dynamics in southeastern North America. In: Anderson DG et al. (Eds), Climate change and cultural dynamics: a global perspective on midHolocene transitions, London: Elsevier, p. 457-489.

ARAUJO AGM. 2008. Geoarqueologia em sítios abrigados: Processos de formação, estratigrafia e potencial informativo. In: Rubin JCR and Silva RT (Eds), Geoarqueologia - Teoria e Prática, Goiânia: Editora da Universidade Católica de Goiás, p. 71-92.

ARAUJO AGM. 2010. Síntese. In: Araujo AGM and Neves WA (Eds), Lapa das Boleiras - Um sítio paleoíndio do carste de Lagoa Santa, MG, Brasil, São Paulo: Annablume/ Fapesp, p. 213-219.

ARAUJO AGM. 2015. On vastness and variability: cultural transmission, historicity, and the Paleoindian record in Eastern South America. An Acad Bras Cienc 87: 1239-1258. 
ARAUJO AGM, FEATHERS JK, ARROYO-KALIN M AND TIZUKA MM. 2008. Lapa das Boleiras rockshelter: Stratigraphy and formation processes at a Paleoamerican site in Central Brazil. J Archeol Sci 35: 3186-3202.

ARAUJO AGM AND NEVES WA. 2010. Lapa das Boleiras Um sítio paleoíndio do carste de Lagoa Santa, MG, Brasil, São Paulo: Annablume/Fapesp, 219 p.

ARAUJO AGM AND NEVES WA. 2012. A Ocupação paleoíndia do sudeste brasileiro: Lagoa Santa e além. In: Morales WF and Moi FP (Eds), Tempos Ancestrais, São Paulo: Editora Annablume / NEPAB, p. 47-71.

ARAUJO AGM, NEVES WA AND KIPNIS, R. 2012. Lagoa Santa revisited: an overview of the chronology, subsistence, and material culture of Paleoindian sites in Eastern Central Brazil. Lat Am Ant 23: 533-550.

ARAUJO AGM, NEVES WA, PILÓ LB AND ATUI JP.2005. Holocene dryness and human occupation in Brazil during the "Archaic Gap". Quat Res 64: 298-307.

ARAUJO AGM, PILÓ LB AND NEVES WA. 2010. Estratigrafia e processos de formação do sítio. In: Araujo AGM and Neves WA (Eds), Lapa das Boleiras - Um sítio paleoíndio do carste de Lagoa Santa, MG, Brasil, São Paulo: Annablume/FAPESP, p. 35-74.

ARAUJO AGM, PILÓ LB, NEVES WA AND ATUI JP. 2006. Human occupation and paleoenvironments in South America: Expanding the notion of an 'Archaic Gap'. Rev Mus Arq Etno 15/16: 3-35.

ARAUJO AGM AND PUGLIESE F. 2010. A Indústria Lítica. In: Araujo AGM and Neves WA (Eds), Lapa das Boleiras Um sítio paleoíndio do carste de Lagoa Santa, MG, Brasil, São Paulo: Annablume/FAPESP, p. 75-106.

ARAUJO AGM, STRAUSS A, FEATHERS J, PAISANI JC AND SCHRAGE TJ. 2013. Paleoindian open-air sites in tropical settings: A case study in formation processes, dating methods, and paleoenvironmental models. Geoarcheol 28: 195-220.

BELTRÃO MC. 1975. Industries lithiques trouvees au cours de la prospection 1971. In: Laming-Emperaire A et al. (Eds), Grottes et abris de la region de Lagoa Santa, Minas Gerais, Brésil- Premier rapport de la Mission Archéologique Franco-Brésilienne de Lagoa Santa, Paris : Cahiers D'Archeólogie d'Amerique du Sud, 1. École Pratique dês Hautes Etudes VIe Section: Sciences Economiques et Sociales, p. 123-130.

BINFORD MW, KOLATA AL, BRENNER M, JANUSEK JW, SEDDO MT, ABBOTT M AND CURTIS JH. 1997. Climate variation and the rise and fall of an Andean civilization. Quat Res 47: 235-248.

BISSARO JR MC. 2008. Tafonomia como ferramenta zooarqueológica de interpretação: viés de representatividade óssea em sítios arqueológicos, paleontológico e etnográfico. MA Thesis, São Paulo: University of São Paulo, 107 p. (Unpublished).
BRADLEY B AND STANFORD D. 2004. The North Atlantic ice-edge corridor: a possible Palaeolithic route to the New World. World Archaeol 36: 459-478.

BUENO LM. 2010. Tecnologia lítica, cronologia e sequência de ocupação: o estudo de um sítio lítico a céu aberto na região de Lagoa Santa, MG. Rev Mus Arq Etnol 20: 91-107.

GOEBEL T. 2013. The northeast Asian origins of the first Americans: Do genes, bones, and stones tell the same story? Quat Int 285: 195.

GOEBEL T, WATERS MR AND O'ROURKE DH. 2008. The late Pleistocene dispersal of modern humans in the Americas. Science 319: 1497-1502.

HENRICH J. 2004. Demography and cultural evolution: how adaptive cultural processes can produce maladaptive losses: the Tasmanian case. Am Ant 69: 197-214.

HENRICH J. 2010. The evolution of innovation-enhancing institutions In: O’Brien MJ and Shennan SJ (Eds), Innovation in cultural systems - Contributions from evolutionary anthropology, Cambridge: MIT Press, p. 99-120.

HISCOCK P. 1994. Technological responses to risk in Holocene Australia. J World Prehist 8: 267-292.

HISCOCK P. 2002. Pattern and context in the Holocene proliferation of backed artifacts in Australia. Archaeol Pap Am Antr Ass 12: 163-177.

HUCKELL B. 1996. The archaic prehistory of the North American Southwest. J World Prehist 10: 305-373.

JUSTICE ND. 1995. Stone age spear and arrow points of the Midcontinental and Eastern United States: A modern survey and reference, Bloomington: Indiana University Press, $304 \mathrm{p}$.

JUSTICE ND. 2002. Stone Age spear and arrow points of California and the Great Basin, Bloomington: Indiana University Press, $448 \mathrm{p}$.

KENNETTDJ, CULLETONBJ, KENNETT JP,ERLANDSON J AND CANNARIATO KG. 2007. Middle Holocene climate change and human population dispersal in western North America. In: Anderson DG et al. (Eds), Climate change and cultural dynamics: a global perspective on mid-Holocene transitions, London: Elsevier, p. 531-557.

KIPNIS R, BISSARO JR MC AND PRADO HM. 2010a. Os restos faunísticos. In: Araujo AGM and Neves WA (Eds), Lapa das Boleiras - Um sítio paleoíndio do carste de Lagoa Santa, MG, Brasil, São Paulo: Annablume/FAPESP, p. 121-147.

KIPNIS R, SANTOS RO AND CEZÁRIO ME. 2010b. A indústria óssea. In: Araujo AGM and Neves WA (Eds), Lapa das Boleiras - Um sítio paleoíndio do carste de Lagoa Santa, MG, Brasil, São Paulo: Annablume/FAPESP, p. 111-119.

LAMING-EMPERAIRE A, PROUS A, VILHENA DE MORAES A AND BELTRÃO M. 1975. Grottes et abris de la region de Lagoa Santa, Minas Gerais, Brésil- Premier rapport de la Mission Archéologique Franco-Brésilienne 
de Lagoa Santa, Paris: Cahiers D'Archeólogie d'Amerique du Sud, 1. École Pratique dês Hautes Etudes VIe Section: Sciences Economiques et Sociales, $185 \mathrm{p}$.

LOURDEAU A. 2015. Lithic technology and prehistoric settlement in Central and Northeast Brazil: Definition and spatial distribution of the Itaparica technocomplex. PaleoAm 1(1): 52-67.

MINGATOS GS AND OKUMURA M. 2016. Modelo de Amplitude de Dieta aplicada a restos faunísticos do sítio Lapa do Santo (MG) e suas implicações para o entendimento da dieta em grupos Paleoíndios do Brasil central. Palaeoindian Archaeol 1: 15-31.

MORENO DE SOUSA JC. 2014. Cognição e cultura no mundo material: Os Itaparicas, os Umbus e os Lagoassantenses. MA Thesis, São Paulo: University of São Paulo, 711p. (Unpublished).

MORENO DE SOUSA JC. 2016. Lithic technology of an Itaparica industry archaeological site: the Gruta das Araras rockshelter, Midwest of Brazil. J Lith Studies 3(1): 87-106.

MORENO DE SOUSA JC. 2017. Paleoindian lithic industries of Southern Brazil: A technological study of the Laranjito archaeological site, Pleistocene Holocene Transition. PaleoAm 3: 74-83.

NEIMAN FD. 1995. Stylistic variation in evolutionary perspective. Am Ant 60: 7-36.

NEVES WA, ARAUJO AGM, BERNARDO DV, KIPNIS R AND FEATHERS J. 2012. Rock art at the Pleistocene/ Holocene boundary in Eastern South America. PLoS One 7(2): e 32228.

NEVES WA, GONZALEZ-JOSÉ R, HUBBE M, KIPNIS R, ARAUJO AGM AND BLASI O. 2004. Early Holocene human skeletal remains from Cerca Grande, Lagoa Santa, Central Brazil, and the origins of the first Americans. World Archeol 36: 479-501.

NEVES WA AND HUBBE M. 2005. Cranial morphology of Early Americans from Lagoa Santa, Brazil: Implications for the settlement of the New World. Proc Nat Acad Sci USA 102: 18309-18314.

NEVES WA, HUBBE M, BERNARDO D, STRAUSS A, ARAUJO AGM AND KIPNIS R. 2013. Early human occupation of Lagoa Santa, Eastern Central Brazil: craniometric variation of the initial settlers of South America. In: Graf K, Ketron C and Waters M (Eds), Paleoamerican Odyssey, Santa Fe: Center for the Study of First Americans, p. 397-412.

O'BRIEN MJ. LYMAN RL, MESOUDI A AND VANPOOL TL. 2010. Cultural traits as units of analysis. Phil Trans Royal Soc B: Bio Sci 365: 3797-3806.

OKUMURA M AND ARAUJO AGM. 2014. Long-term cultural stability in hunter-gatherers: a case study using traditional and geometric morphometric analysis of lithic stemmed bifacial points from Southern Brazil. J Archaeol Sci 45: 59-71.
OKUMURA M AND ARAUJO AGM. 2016. The Southern Divide: Testing morphological differences among bifacial points from Southern and South-eastern Brazil using geometric morphometrics. J Lith Studies 3: 107-132.

PALMER CT. 2010. Cultural traditions and the evolutionary advantages of noninnovation, In: O'Brien MJ and Shennan SJ (Eds), Innovation in cultural systems: Contributions from evolutionary anthropology, Cambridge: MIT Press, p. 161-174.

PEREZ CP. 2009. Paleoecologia de mamíferos viventes como ferramenta na caracterização do ambiente holocênico de Lagoa Santa, MG. MA Thesis, São Paulo: University of São Paulo, 112 p. (Unpublished).

PUGLIESE FA. 2007. Os líticos de Lagoa Santa: um estudo sobre organização tecnológica de caçadores-coletores do Brasil Central. MA Thesis, São Paulo: University of São Paulo, 154 p. (Unpublished).

RACZKA MF, OLIVEIRA PE, BUSH M AND MCMICHAEL CH. 2013. Two paleoecological histories spanning the period of human settlement in southeastern Brazil. J Quat Sci 28: 144-151.

ROWLAND MJ. 1999. Holocene environmental variability: have its impacts been underestimated in Australian prehistory? The Artefact 22: 11-48.

SANTOS RO. 2011. As tecnologias esqueletais: uma investigação as matérias-primas de origem esqueletal por meio de análise comparativa entre coleções arqueológicas e etnográficas. MA Thesis, São Paulo: University of São Paulo, 103 p. (Unpublished).

SHENNAN SJ. 2000. Population, culture history, and the dynamics of culture change. Curr Anthr 41: 811-835.

SHENNAN SJ. 2001. Demography and cultural innovation: a model and its implications for the emergence of modern human culture. Camb Archeol J 11: 5-16.

STANFORD D AND BRADLEY B. 2012. Across Atlantic Ice: the origin of America's Clovis Culture, Berkeley: Univ of California Press, $336 \mathrm{p}$.

STEIN JK, KORNBACHER KD AND TYLER JL. 1992. British Camp shell midden stratigraphy. In: Stein JK (Ed), Decyphering a shell midden, New York: Academic Press, p. 95-134.

STEWARD J. 1963. Theory of culture change. The methodology of multilinear evolution. Urbana: University of Illinois Press, 244 p.

STRAUSS AM. 2010. As práticas mortuárias dos caçadorescoletores pré-históricos da região de Lagoa Santa (MG): Um estudo de caso do sítio arqueológico "Lapa do Santo". MA Thesis, São Paulo: University of São Paulo, 717 p. (Unpublished).

STRAUSS AM ET AL. 2015. The oldest case of decapitation in the New World (Lapa do Santo, East-Central Brazil). PLoS ONE 10(9): e0137456. 
TELTSER PA. 1991. Generalized core technology and tool use: a Mississippian example. J Field Archeol 18: 363-375.

VANPOOL TL AND SAVAGE C. 2010. War, women, and religion: The spread of Salado Polychrome in the American Southwest, In: O'Brien MJ and Shennan SJ (Eds), Innovation in cultural systems - contributions from evolutionary anthropology, Cambridge: MIT Press, p. 251265.

WENINGER B, JÖRI O AND DANZEGLOCKE U. 2012. CalPal-2007. Cologne radiocarbon calibration, palaeoclimate research package. http://www.calpal.de/, accessed 2015-09-19. 